\title{
Mobilities, Individuation, and Agencies: An Analysis Based on Young Migrants' Biographical Narratives in Buenos Aires, Argentina
}

\author{
Silvia Alejandra Tapia \\ University of Buenos Aires, Argentina \\ Pablo Francisco Di Leo \\ University of Buenos Aires, Argentina
}

DOI: https://doi.org/10.18778/1733-8077.17.3.06

Keywords:

Migration;

Youth; Mobility;

Individuation;

Agency

\begin{abstract}
Social studies point out the unequal conditions for moving or staying, internally or internationally, that young people from different social sectors face in their biographies. In this article, we analyze the migratory experiences of young people from popular sectors of the Metropolitan Area of Buenos Aires, Argentina. To do that, we put into dialogue recent studies on migration and proposals of the sociology of individuation and the new mobility paradigm. We approach the individuation processes of these young people through the qualitative analysis of their biographical narratives in which their migration experiences emerged as turning points in their lives. The article argues that young migrants from popular sectors draft their agencies and shape themselves as individuals by mobilizing material and symbolic supports and accessing different social shock-absorbers that allow them to cope with three major social challenges in their migratory processes: the socio-labor trial; the family trial, and the identity trial. By identifying the discontinuities and the common evidence present in the migratory experiences of these young people and their families, the paper ends highlighting the articulations among coercions, elasticities, and strategies that these youth migrant mobilize, individually and collectively, around themselves and others, through border-links to create shelters and deal with such challenges.
\end{abstract}

Silvia Alejandra Tapia is an Assistant Researcher at the National Scientific and Technical Research Council, Argentina. She is a Professor in the Sociology Department at the University of Buenos Aires. Her research interests cover areas such as qualitative studies of youth, mobilities, body/emotions, and education.

email address: tapiasilvi1@gmail.com
Pablo F. Di Leo, Ph.D., is an Independent Researcher at the National Scientific and Technical Research Council, Argentina, and a Professor in the Sociology Department at the University of Buenos Aires. His publications include numerous articles in scientific journals, chapters, and seven books edited on individuation processes, agency, youths, biography, institutions, drug use, health, care, and rights.

email address: pfdileo@gmail.com 


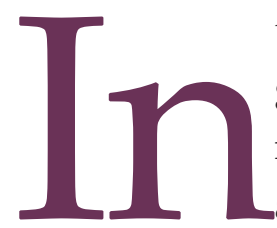

the last ten years, social research began to distinguish the peculiarities in young migrants' mobilities. These Lanalyses point out the unequal conditions for moving or staying-internally or internationally-present in young people's biographies from different social sectors, as the economic and social consequences that these mobilities cause in their families and places where they move around (Frändberg 2014; van Geel and Mazzucato 2018).

Such approaches introduce young people's experiences and agencies as relevant dimensions for the study of migratory processes (Dako-Gyeke 2016; Lee 2016; Moskal and Tyrrell 2016; Kok, Coetzee, and Elliker 2017). Looking to recognize children and youth as subjects of rights and independence, the first inquiries tended to observe their experiences as individual actions and disconnected from the family environment. However, from the recent critical perspectives, youth mobilities are identified as relational processes and in a continuum of independence/dependence concerning their family bonds (Mikkelsen and Christensen 2009; Giralt 2016).

To understand young people's experiences, some authors go back to the concepts of the second or third generation. Notions that were discussed because of their static character, based on ethnic condition or the role in the family, that makes invisible the multiple dimensions of the youth identities go through in migratory processes (Raffaetà, Baldassar, and Harris 2016).

Other analytic proposals associate the transition processes between geographic spaces and transitions to adulthood (Punch 2015; Huijsmans 2018). These transitional approaches, prevailing in the studies about youth, set out the idea of some milestones, especially linked to the education, labor, or family, as needed steps to adulthood. Such perspectives-with a sense of progressive or lineal development of being young-tend to (re)produce static, homogenizing, and adult-centric visions of youth. Although they recognize possible discontinuities in modern societies, they thrive on the notion of common stages to get through adulthood and the use of the term transition (Skelton 2002; Coulter, van Ham, and Findlay 2015; Roberti 2017). Distancing us from such approaches, we consider social transformations of the last decades, that de-standardize and singularize trajectories, require new analytic lectures like the ones that the sociology of experience (Dubet 2010) and sociology of individuation (Martuccelli 2007) -we will go back to this perspective and develop it in the following section.

In many studies taking place in Latin America about young people's experiences, tensions arise between the static and homogenizing perspectives about children and youth, based on biological, psychological, or unilateral sociological definitions, and, on the other side, conceptions that exaggerate the fragmented and momentary character of young identities (Reguillo 2012). Both analytic postures contribute to reproducing the negation and negativization processes of the young people-especially in popular sectorstheir existence as total subjects is denied (in transition, incomplete), and their practices are relativized (youth-problem, young-deflected, rebel, marginal, and criminal, among other stereotypes) (Chaves 2010). Facing these dichotomous conceptions, thinking of the youth from the notion of generation, allows us to visualize those socio-historical aspects that delimit common settings of socialization, as well as the capacity of the actors for the comprehension and identification of a series of common challenges that they encounter in a specific historical moment (Di Leo and Camarotti 2015; Vommaro 2015). 
The research findings reported here are framed within a doctoral thesis and three financed projects in which we analyze the bonds between the social inequalities, experiences, and processes of individuation of young people belonging to popular sectors in diverse regional and institutional contexts in the Metropolitan Area of Buenos Aires (MABA), Argentina (Di Leo and Camarotti 2013; 2015; Tapia 2016; 2019; Di Leo and Arias 2019). In the last of these projects, we inquired into the involvement experiences and the intergenerational bonds of young people in social institutions and organizations that promote, in popular neighborhoods, the access and exercise of rights. In these studies, we approached their (im) mobilities, affections, and bonds, since their articulations and tensions are present in the biographies and personal trajectories. To do that, we went back to the theoretical framework of the sociology of individuation by Martuccelli (2007) and Araujo (Araujo and Martuccelli 2012), looking to identify the social trials presented in their biographies, as well as their works and supports they use to overcome such challenges.

Going back to the results of such investigations, in this article, we focus our attention on the following questions-problems: What characteristics and senses represent the migratory mobilities in the young biographies of popular neighborhoods? What social trials are connected to such migratory processes? Which supports these young people and their families make use of when facing such challenges? How do the agencies of these people draft themselves concerning such evidence and social support?

As we develop in this work, the main finding of our research is the identification of three big social challenges or trials in which young migrants from popular sectors draft their agencies and shape themselves as individuals, moving various supports and accessing or drafting different social shock-absorbers that allow them to face multiple risks and vulnerabilities:

A. Socio-labor trial: searching for a job and housing is one of the young people and their families' main motivations when they want to move internally or internationally. ${ }^{1}$ In this search, multiple displacements cause significant biographical changes in their narratives.

B. Family trial: the tensions and conflicts in the shaping, the maintenance, the regrouping, or even the breakdown of relationships, as well as the new bonds and affections linked to the familiar are significant for the young in their migratory processes.

C. Identity trial: the different forms of discrimination given in their biographies are lived as authentic challenges for the young people, to which they have to spread several tactics to get accepted or integrated into public or private spaces.

This article is organized in the following way: first, we review the perspectives of agency, sociology of individuation, and the new paradigm of mobilities. Then, we present the methodological strategies we followed for the construction and data analysis from biographic narratives. Third, we develop the results from our analysis taken from the young migrants' biographical narratives, organized around the three main social trials mentioned in their individuation processes. In the conclusions, from the summary and articulation

\footnotetext{
${ }^{1}$ According to King and Skeldon (2010), we understand that the historical differentiation between the internal and international migrations needs to be discussed. Such distinction was based on the differentiation between the politics and symbolic boundaries, the number of people who mobilize, the covered distances, or the linguistic and cultural barriers. Whereas, we consider the (im)mobilities from their complexity, advising their tensions and articulations, which exceed such standards.
} 
of such challenges, we consider the drafting of young people's agencies and identities in popular sectors concerning their migratory experiences.

\section{Theoretical Framework}

One group of theoretical and methodological approaches in social sciences is focused on the problem of social order, which would be a product of a series of emerging structures (political, economic, symbolic, and cultural) and coercions (a structured forced system) that articulate and interpenetrate the different social actions between each other. From an opposite analytic posture, a group of philosophical currents and social theories are faced by the biologist, economist, culturalist, and/ or structuralist determinism, putting the topic of the actor's freedom in the center. Facing these dichotomy positions (and simplifiers), Martuccelli (2016) proposes to put the problem of the agency in the center of new sociological questions: What specific social characteristics make it possible to always act in a different way? Based on some of his empirical and theoretical research, this author proposes an ontological answer to this inquiry: "Social life can be defined metaphorically as an area with resistant malleability among variable elasticities" (Martuccelli 2016:18 [trans. SAT and PFDL]).

As in social life, there are a thousand layers of textures (cultural and symbolic) and coercion (economic and political) that operate in an irregular, sporadic, and variable way; the agency is possible, that is to say, we always can act in many ways. This does not mean renouncing the existence of clashes with reality but making the sociological analysis of such encounters more complex. The individuals permanently act in various social and elastic in-between-worlds that make the moments of encounter with reality more complex. This deviation of the perspectives allows us to understand, for example, the multiplication of strategies developed by different actors-individual and collectives-to get access to social shock-absorbers that allow them to protect themselves from the risks (economic, political, environmental, and/or sanitary) multiplied in the current stage of modernity (Martuccelli 2016).

The narrow homology between social inequalities, collective identities (social class, gender, race, generation), and personal experiences discloses with less effectiveness than in the mid-twentieth century, under the increased amount of anomalies, uncertainty, and possibilities that characterize our globalized societies. As Araujo and Martuccelli (2010; 2012) analyze, in Latin-American societies, most of the individuals feel that their social positions are inconsistent, which leads them to spread several practices directed to anticipate and protect themselves against threats. The subjects build a series of singularized refuges, combining the following: a) a heterogeneous group of social and state shock-absorbers (for instance, the infrastructure of public services, social rights, and family support); b) cognitive capacities, forms of reflexivity to identify the exact nature of the threatening risks; c) collective and individual possibilities of risk factors control. Taking these actors' strategies in the sociological analysis of inequalities into account "allows us to describe, more precisely, the differences between the individuals and understand what these differences produce politically" (Martuccelli and Santiago 2017:140 [trans. SAT and PFDL]).

During many decades, social sciences-considering uncritical theories and metanarratives originated in central countries - have cast doubts on the existence of individuals in the peripheral societies; and, especially, they have denied that condition to members of socially subordinated groups (like women, children, young people, poor, and migrants). “These people were seen 
as anomalies and so, other modalities of individuation were invisibilized" (Araujo and Martuccelli 2014:25). To get through these epistemological barriers, Martuccelli (2007) and Araujo (Araujo and Martuccelli 2012) develop social research in France and Chile in which they identify and articulate the structural trials and the supports concerning which the actors are constituted as individuals. There is no individual without a group of supports-affective, material, and symbolic-that are spread in their biography. They function as long as they remain under a threshold of consciousness. Some occur at the interchange between the inner worldsfunctioning as individual self-support-and external, objectified as a support for the subject. They also use the concept of social trials, defined as:

structural and historical challenges socially produced, culturally represented, unequally distributed that individuals-all and each of them-are forced to face within society. The notion of trial, therefore, proposes, like so many others, an articulation between the structural processes and the personal experiences, but where other notions, for example, the theory of socialization, seek to establish the necessary bonds...the study for evidence leaves this relationship always open, and therefore, problematic. [Araujo and Martuccelli 2012:16-17 (trans. SAT and PFDL)]

This concept is constructed by articulating two analytical levels: on the one hand, it starts from the narratives through which individuals express themselves; and, simultaneously, it constructs an analytical representation that distances itself from concrete narratives, seeking to relate socio-historical changes and the actors' lives (Martuccelli 2007; Araujo and Martuccelli 2012).

The recent analyses of the migratory processes also cause tension and re-signify the concepts about society and individuals. The approach of the new par- adigm of mobilities (Sheller and Urry 2006) allows us to notice that studies about migratory processes have been sustained in static notions of territories and cultures associated with them. This does not mean considering the moving as newness or a more moving contemporary world than in the past. Nor prioritizing flows, the speed over the fixed, and the stable.

Such an approach proposes, instead, to recognize the intersections between the mobilities and immobility of people, objects, images, money, or information, problematizing the positive exaltation of freedom to move that does not question the conditions that lead or limit the movement of people. In this sense, how certain mobilities are regulated and limited by legal, economic, or symbolic restrictions are tracked, while others are allowed, motivated, or desired (Salazar and Smart 2011). Thus, the aim is to identify the different capacities to be mobile-or to be immobile, to remain-deployed by the agents. These capacities are unevenly distributed among different social groups (Kaufmann, Bergman, and Joye 2004).

\section{Methodology}

Taking up previous studies made by our team, we approach the processes of individuation and mobility of young people through the qualitative analysis of their biographical narratives. Qualitative research seeks to increase our understanding of society from the meanings that individuals assign to their experiences (Denzin and Lincoln 2011). Framed in this paradigm, biographical methods are oriented to the analysis of the relations between the individual and the society-they give an account of the lived experiences and the senses attributed to them and, at the same time, allow us to understand how they are inserted in certain historical, social, and cultural conditions. It seeks to transcend the particular case through interpretive procedures 
that approach the interrelations between the personal, the historical, and the social in their mutual constitution (Chamberlayne, Bornat, and Wengraf 2000).

In this sense, Wolfram Fischer-Rosenthal (2000), in dialogue with the sociologies of Simmel and Luhmann, among others, proposes the conceptual tool of biographical structuring to connect the individual and the social-subject and object, citizen and State-in the present stage of modernity. Biographical structuring is a practice and a form of temporalization through which individuals, institutions, and societies can deal with the growing contingencies, sustain complex social structures, to interpret and balance the multiple options they face daily.

Bertaux and Bertaux-Wiame (1980) use the biographical method to carry out a typological analysis of bakers in Paris. To do this, they use the procedure of informative saturation, consisting of the accumulation of stories of different individuals of the same social category to construct, from these stories, a single one. Both this typological analysis and the representativeness standards-which Pujadas-Muñóz (1992) proposes that should guide the selection of informants to fit a certain social type-are inadequate in a context characterized by the increasing singularization of biographical trajectories in the current stage of modernity (Araujo and Martuccelli 2014).

Therefore, we consider the epistemological, ethical, and methodological position of Michèle Leclerc-Olive (2009), who propose the use of biographical narratives, ${ }^{2}$ more relevant for our study. According to the

\footnotetext{
2 There are some distinctions between the terms stories and narratives. Stories have narratives embedded in them in addition to interweaving elements. Narratives are intersubjective co-constructions of meaning involving a narrator, a listener, and the linguistic and social rules of interpersonal communication (Kohler Riessman 2008; Corbally 2011).
}

author, these biographical narratives have two main characteristics: they are performative, that is, they are the narratives that institute a story; they are referential because, having their roots in the actors' experiences, they also belong to the historical-sociological genre. In her research works, she seeks to analyze the heterogeneity of the temporalities of individuals-even within the same social category-from the construction the actors make of their biographical narratives around the significant events pointed out by them. ${ }^{3}$

The articulation between the performative and referential dimensions of biographical narratives occurs around significant events, turning points or turns of existence: nodal points of biographical experience; moments when the representations of the individual around oneself, society, and the world are altered (Lincoln and Denzin 2003; Leclerc-Olive 2009). These are situations where the subjects question themselves, interpret, and try to find meaning, produce new theories about their world:

a biographical event is an intersubjective and shared experience....Although during the meeting with the researcher, whole parts of the set time of "prefabricated narratives" are available, the exchange can allow the emergence of hidden memories, the formation of new configurations, or unknown reconciliations. In any case, recovery coexists with co-production. What makes the meeting with the researcher exceptional is the journey of the biography that is carried out jointly and that allows a relatively distant look. [Leclerc-Olive 2009:19-20 (trans. SAT and PFDL)]

\footnotetext{
${ }^{3}$ In this sense, we agree with the theoretical-methodological proposal of Gómez-Esteban (2016); and we differentiate ourselves from other recent studies, such as that of Pac-Salas and Ventura de Pedro (2015). Such studies use the life story method to study the influences of classical social institutions (family, education, labor market) and class on the transitions of young people to adult life, putting analytical emphasis on social continuities rather than on individual heterogeneities.
} 
In our research, the construction of the biographical narrative was agreed upon throughout five or six interviews with each young person. We began the first meeting with a question aimed at accessing their subjective self-identifications: "If you had to tell me who you are, what would you say? How would you describe yourself?" Then, we proposed to them to identify the most significant events in their lives: "If you had to choose the main moments or situations that caused very important changes in your life, what would they be?" During two or three subsequent meetings, we suggested that young people describe and consider each of the significant events they identified, which we wrote down and recalled in the course of the interviews.

Around the fourth or fifth meeting, we asked interviewees to order the selected events on a sheet of paper as they wished and explain why they decided to do so. The theoretical-methodological justification for this "putting on paper" of the significant events lies in the fact that they "constitute the narrative framework of the narratives and have a temporality function: they are not placed on dates of a pre-existing calendar but build a personal calendar" (Leclerc-Olive 2009:4 [trans. SAT and PFDL]).

After each meeting, the transcripts of the previous interview are returned to the young people so that they can introduce the desired modifications. In the last interviews, we propose to them the first draft of their biographical story, written in the first person based on the interviews transcribed and corrected, organized in chapters corresponding to each of the events identified and ordered by them. The consensual writing of the biographical story ends when young people consider that they no longer have anything to add or modify. As a final product, texts that narrate and organize in a personal way the events considered most significant in their lives are obtained. These documents have a dual purpose: first, they constitute objects of value for each subject interviewed, since they are their biographical narratives; second, they are valuable materials for sociological analysis, without replacing the interviews per se (Di Leo and Camarotti 2013).

\section{Sample}

The conformation of the sample, following the guidelines of grounded theory, responds to the permanent search for categories, their properties, and articulations between data and theory. Its delimitation is based on the standard of theoretical saturation, that is, to notice when a new case no longer allows providing additional information for the construction of new categorizations (Glaser and Strauss 1967). In our research, the young people were contacted through their participation in institutions and community organizations, located in the MABA's popular neighborhoods, which offer education, work, and spaces of sociability and recreation free of charge: secondary schools, popular high schools (bachilleratos populares), ${ }^{4}$ churches, health centers, a social circus, and a labor cooperative (COOPA). A total of 35 young people (18 males and 17 females) between the ages of 16 and 26 who live in these neighborhoods (see Table 1) took part. For their selection, we used different diversification criteria: age, sex, spaces of sociability, neighborhoods, and educational levels. Ethical aspects such as anonymity and informed consent were considered in each case.

\footnotetext{
4 Bachilleratos populares are middle-level schools for young people and adults created by social organizations located in vulnerable neighborhoods of Argentina. They are recognized as self-managed spaces. They develop political-pedagogical practices with territorial anchorage, following the proposals of emancipatory Latin American popular education. They seek to facilitate school completion and encourage citizen training processes, through the dispute of senses around the territorial and educational (Aguiló and Wahren 2014; Said 2018).
} 
Table 1. Profile of young people interviewed

\begin{tabular}{|c|c|c|c|c|c|c|}
\hline PSEUDONYM & AGE & GENDER & $\begin{array}{l}\text { PLACE OF } \\
\text { RESIDENCE }\end{array}$ & SCHOOL LEVEL & $\begin{array}{c}\text { OCCUPATION/ } \\
\text { EMPLOYMENT STATUS }\end{array}$ & $\begin{array}{l}\text { MARITAL STATUS / } \\
\text { CHILDREN }\end{array}$ \\
\hline Carlos & 26 & Male & CABA & High school (incomplete) & Employee & Single / No children \\
\hline Charly & 26 & Male & GBA & High school (complete) & Employee (family business) & Single / No children \\
\hline Dora & 20 & Female & CABA & University (incomplete) & Student & Single / No children \\
\hline Facu & 19 & Male & CABA & High school (incomplete) & Student & Single / No children \\
\hline José Luis & 23 & Male & GBA & Elementary school (incomplete) & Employee & Single / No children \\
\hline Juana & 20 & Female & CABA & University (incomplete) & Student & Single / No children \\
\hline Julito & 26 & Male & CABA & High school (incomplete) & Employee & Single / No children \\
\hline Lili & 23 & Female & GBA & High school (incomplete) & Housemaid & Single / No children \\
\hline Nora & 19 & Female & CABA & High school (incomplete) & Employee & Single / No children \\
\hline Purly & 18 & Male & GBA & High school (incomplete) & Student / Employee & Single / No children \\
\hline Iván & 23 & Male & CABA & Pre-university (in progress) & Student / Informal jobs & Single / No children \\
\hline Omar & 20 & Male & CABA & High school (incomplete) & Informal jobs & Single / No children \\
\hline Gustavo & 20 & Male & GBA & University (in progress) & Unemployed & Single / No children \\
\hline Lolo & 18 & Male & CABA & High school (in progress) & Unemployed & Single / No children \\
\hline Nicolás & 18 & Male & CABA & High school (in progress) & Unemployed & Single / No children \\
\hline Sofía & 18 & Female & CABA & High school (complete) & Unemployed & Single / No children \\
\hline Chinita & 20 & Female & CABA & University (in progress) & Student / Not working & Single / No children \\
\hline Romina & 19 & Female & GBA & High school (complete) & Unemployed & Single / No children \\
\hline Edrul & 19 & Male & CABA & High school (incomplete) & Employee (family business) & Single / No children \\
\hline Solanch & 20 & Female & CABA & High school (complete) & Employee & Separate / 2 children \\
\hline Mateo & 23 & Male & CABA & High school (complete) & Unemployed & Single / No children \\
\hline Ramona & 23 & Female & GBA & High school (in progress) & Student / Housemaid & $\begin{array}{c}\text { Lives with partner / } \\
3 \text { children }\end{array}$ \\
\hline Alberto & 21 & Male & GBA & High school (in progress) & Student / Unemployed & Single / No children \\
\hline Carla & 24 & Female & GBA & High school (in progress) & Student / Informal jobs & Single / 1 child \\
\hline Juan & 21 & Female & CABA & High school (in progress) & $\begin{array}{l}\text { Student / Employee (state } \\
\text { program) }\end{array}$ & $\begin{array}{c}\text { Lives with partner / } \\
3 \text { children }\end{array}$ \\
\hline Fatu & 18 & Female & CABA & High school (in progress) & Student / Housemaid & $\begin{array}{c}\text { Lives with partner / } \\
\text { Pregnant }\end{array}$ \\
\hline Víctor & 19 & Male & GBA & High school (complete) & Informal jobs & Single / No children \\
\hline Tincho & 18 & Male & CABA & High school (in progress) & $\begin{array}{l}\text { Student / Temporary } \\
\text { internship }\end{array}$ & Single / No children \\
\hline Mariana & 17 & Female & CABA & High school (in progress) & Student / Employee & Single / No children \\
\hline Jorge & 18 & Male & CABA & High school (incomplete) & Unemployed & Single / No children \\
\hline Liz & 21 & Female & CABA & High school (complete) & Unemployed & Single / No children \\
\hline Miguel & 18 & Male & GBA & High school (in progress) & Student & Single / No children \\
\hline Pecosa & 16 & Female & GBA & High school (in progress) & Student & Single / No children \\
\hline Fernanda & 17 & Female & GBA & High school (in progress) & Student & Single / No children \\
\hline Susana & 16 & Female & GBA & High school (in progress) & Student & Single / No children \\
\hline
\end{tabular}

Source: Self-elaboration. 


\section{Study Context}

The research presented here is located in the Metropolitan Area of Buenos Aires (MABA), Argentina, in southern Latin America. This area is composed of the Autonomous City of Buenos Aires (CABA) and a suburban sector formed by 24 municipalities (GBA). The CABA is the capital city of Argentina, which centralizes the political and administrative organization of the country, as well as economic and service activity. Due to its economic and demographic growth, it expanded its limits to the so-called GBA, establishing itself as the largest urban agglomeration in the country with a population that, according to the 2010 National Census, exceeds 15 million inhabitants. The area as a whole presents important social and economic inequalities expressed in growing segregation and urban fragmentation (Di Virgilio, Marcos, and Mera 2015; Cravino 2016). The neighborhoods, where the young people interviewed live and where the chosen institutions are found, are located in the south and west of the MABA, in areas of greater social and educational vulnerability.

\section{Process and Analysis}

Following the strategy of constant comparison proposed by grounded theory (Strauss and Corbin 1990), we construct, encode, and analyze the data corpus simultaneously, using as an auxiliary software ATLAS.ti. All of the interviews were coded and transcribed in the most literal way possible in text files, recording silences, laughter, significant intonations, and all the information relevant to contextualize the situations in which we applied the techniques. We controlled the transcripts by listening to the recordings and, in the necessary cases, corrected them and incorporated other data that we would have remembered later. As we corrected the documents, we incorporated them into a hermeneutic unit, previously created in ATLAS.ti. We made new readings of the corpus, making the first codifications of it from two complementary procedures:

- Top-down codification: Taking up our previous conceptual work and the main dimensions of interviews and narratives, we formulated the first list of codes, which we applied to the documentary corpus to make a first classification of information.

- Bottom-up codification: We were incorporating new codes and modifying the existing ones as we identified relevant topics, information, and nucleus of meaning from the reading and rereading of interviews and narratives.

At the end of the coding work, we grouped the codes into families, according to affinities in the themes, meanings, or their links with concepts coming from the theoretical framework and the state of art-which we finished building in dialogue with the data. Using the different search tools of ATLAS. ti, we made specific excerpts of interviews and narratives, combining in different ways the codes, the families, and the different types of primary documents that made up the hermeneutic unit. From these new readings, we wrote down notes or memos and networks in which we outlined possible relationships between codes, families, and emerging categories (Chernobilsky 2007). In turn, these new operations of classification and rereading of the corpus facilitated our work of constant comparison-between the narratives, the categories, and the theoretical-conceptual framework-from which we formulated new questions and identified the central categories. 
In this way, through the successive back and forth between theoretical assumptions and (re)readings of interviews and narratives co-constructed with young people, we identified three major structural challenges that go through their migration experiences and concerning which their agencies are configured: socio-labor trial; family trial; identity trial. In the next section, we will develop our analysis around each of them.

\section{Results}

\section{The Socio-Labor Trial}

The detailing of neoliberal reforms in the 1990s caused a major economic, political, and social crisis towards the end of 2001 in Argentina (Vaccotti 2017). In such context, the interviewees as children, and their parents being young, travel from countries like Bolivia, Peru, or Paraguay and provinces of northern Argentina to the MABA. As other studies point out, migrations in the region have been traversed by the intention to transcend limitations in access to land and labor opportunities (Punch 2007; Crivello 2015). From the narratives of our interviewees, we note that their displacements are oriented, especially, in two directions: the location of housing associated with their potential access to schools and work, and the meeting with relatives who have previously traveled. In this search, their movements involve multiple transitions between and within different cities. At the beginning of his story, Iván ${ }^{5}$ ( 23 years old) introduces how these mobilities mark his biography.

I was born in Salta. I moved here when I was a kid, my parents came. And we had quite a life moving from

\footnotetext{
${ }^{5}$ In the presentation of the results, we have replaced the names of the interviewees with pseudonyms.
}

one place to another. We only settled down when I was 13 years old. And for the last 10 years, I have been living in the same place since then. [Iván]

These movements lead Iván and his family to live in different types of housing with different tenancy modalities: from living in a "shed" and renting different properties to buying a house with the help of other family members. These displacements caused constant changes in school, being in charge of the care of younger siblings, or household chores. Although he experiences loneliness and discomfort in this process, he mentions this process as a necessary work done by his parents to improve the quality of family life.

For these families, due to the costs of housing in the MABA, one of the most common options has been to settle in marginal areas, particularly in neighborhoods called villas ${ }^{6}$ (Vaccotti 2017). Nora (19 years old) points out in her biographical account the arrival to one of these neighborhoods and the limitations of her first home.

We are from a town in Paraguay. When we arrived, we went to live in a house with only one room, a bathroom, and a kitchen. We all slept together in the same bed. Then my uncle died (he lived in front of my house); we bought the property from his children and we expanded. [Nora]

Another residential option has been the boarding house hotels. Collective housing is centrally located in the city, informally contracted, characterized by high overcrowding and poor building conditions

\footnotetext{
${ }^{6}$ Villas are informal urban developments resulting from unplanned occupations of vacant urban land. They have a high population density and housing built with precarious materials. Their inhabitants are mostly informal or low-skilled workers to whom stigmatizing characteristics are often attributed.
} 
with high rental prices per room (Marcús 2017). Two of the interviewees pointed out their passage through this type of housing upon their arrival in Argentina.

As soon as I came from Peru... and from there we left because, supposedly, the building where we were in was being rented, you see, and no, it was not being rented, it was being taken over. [Juan]

I was living in Once [neighborhood's name] until the building was demolished, they threw it down. And, well, we had nowhere to go and my aunt who lives here [villa] also in the neighborhood, a long time ago, she is the first of all, let's say... She gave us a piece of land there, which was empty. And well, we built our house there. [Fatu]

Cotton and Schwartz-Barcott (2016) identify among low-income families in the United States that problems with property owners, the deterioration of their homes, and social and family violence are reasons for continuous relocations, generating quasi-permanent conditions of residential instability. The unequal living conditions and possibilities of deciding on migratory and residential mobilities require, therefore, not only the ability of different social groups to be mobile (motility), but also their ability not to move (Schrooten, Salazar, and Dias 2016). In the case of the interviewees and their families, even when residential precariousness and instability force their transit between multiple dwellings, family networks that enable access to land, and even to their homes, facilitate their possibilities of settling down.

In the family decisions present in the migratory processes, labor insertion is also fundamental. Edrul (19 years old) resides with his family in the outskirts of a villa in the south of the city. They established their textile business, which they had already been developing in Bolivia. After his father's death, he is forced to drop out of high school and take over the workshop. De Freitas (2014) analyzes the migratory processes of young Bolivians in textile workshops organized by other Bolivians in São Paulo and the MABA. Ethnic discrimination and limited options in those cities limit labor opportunities in other areas for these young people. Edrul had sought to avoid working in the workshop before his father's death. In his story, he reports the difficulties in finding steady jobs, but does not associate them with his migratory status.

And I'm there in those decisions of... looking for a job that more or less gives you freedom [what do you imagine that can give you "freedom?"] Freedom. A job where... a creative job could be... I feel that the circus could be one, but I feel that it's not very... it's difficult, the circus is difficult...Instability is what worries me the most. The instability and the payment, I guess. If I was on my own, I wouldn't mind, but since I have siblings and I have a mother, my father is gone, so I have to help out with something, right? [Edrul]

In his job choice, the tensions between family and responsibilities, the search for salary stability, and the interest in pleasant work practices are expressed. Participating in the social circus enables Edrul to imagine a job as an artist and to question his perception of work. However, the familiar will ultimately have more weight in his decisions.

In other cases, instability and informality of access to housing and work require young people to alternate their place of residence between different cities for limited periods. For Julito, in the transit between Argentina and Paraguay, such mobility is linked to a difficult process the young man undergoes due to 
his problematic drug use, which even leads him to live several months on the streets in the MABA.

I have been using it for 10 months. I was on the street, I no longer bathed, I no longer gathered to buy clothes, nor to pay the rent. And there I talked to my boss, you see, he trusted me because I never touched anything, even though I used drugs I never touched anything. I told him that I wanted to go to an institution, that if he knew of any institution around there. And one day he took me to talk to Pepe, I mean, he went to talk, I didn't, I was really bad, I couldn't speak. And he took me on his motorcycle. [Julito]

Faced with health and housing problems, such as those experienced by Julito, the presence of another person who helps, listens, and trusts becomes a support for him. Support that is material and economic in the face of the possibility of sustaining a job or being taken to an institution for treatment and that is, at the same time, affective support valued for the possibility of feeling understood and accompanied.

\section{The Family Trial}

In the interviewees' experiences, migratory (im)mobility causes temporary and permanent separations from parents, children, or partners. They make possible, in turn, new configurations of family groups. One of the conditions that transform families is related to the migrations of the interviewees' mothers motivated by the search for a job. Female labor migration in Latin America has caused significant changes in the conformation and reorganization of care networks, as well as in gender and generational relations (Gil Araujo and Pedone 2014; Martelotte 2015).

For José Luis (23 years old), his mother's leaving in search of a job is associated with emotions of pain, but also of "anger." For Fatu (18 years old), his mother's continuous trips between Paraguay and Argentina cause her contradictions about the mother figure.

I grew up with my grandparents since I was 11 months old and I called them "mom and dad." I didn't know my mom was my mom. She was in a relationship and she had my little brother with my stepfather. And my brother was born here and they went there. And when I was 7 years old, my mom brought me here. But, then I cried and cried because I didn't want to come because I said she wasn't my mother...I used to see her as my aunt. [Fatu]

The permanence or relocation of mothers produces anger in the face of situations considered as abandonment and the uncertainty caused by the encounter with other relatives. Fatu's discomfort is associated with the diffused nature of the bond with her mother and the effects of her (im)mobilities on other bonds: she is her grandparents' "daughter," her "aunt" is her mother, and she must live with a stepfather and a new brother. Crivello (2015) analyzes the migration experiences of young Peruvians and their families in which decisions to migrate appear chaotic and fragmented. However, the intentions behind such decisions are grounded in strengthening the family. In the case of our interviewees, although the search for greater family well-being is valued, for young people, the departure of fathers and mothers is experienced as a difficult and painful process.

After the mobilities, the young people also distinguish conflicts and violence in their families based on the contrast with other dynamics and customs. Iván identified two family configurations: "inside," a conflictive family way, and "outside," a collaborative and friendly way. 
A partner invited me to his house and up to that moment... as we come from Salta, we don't know what other families are like. We have our own family, our own mess...Then I started to see what other families were like. And there were comparisons: "Why do they get along so well with each other and we fight all the time?" His father was very extroverted, he talked a lot with his son, and so was his mother. It was like creating a different environment. [Iván]

Kleidermacher (2017) inquired into the representations of Senegalese migrants about their life in the CABA. In their narratives, they contrast their values linked to family and to moments of encounter such as dinner time-even in contexts of precariousness in which they live-with the individualism they observe in Argentine. The contrasts between routines and ways of bonding make it clear to Iván that, even when changing residence, the same family habits and conflicts are maintained. However, finding another family space, where the interaction among its members is warm and joyful, causes a before and after in his biography. An environment that becomes valued affective support.

Migratory movements diversify the spaces of sociability that mobilize, in turn, the meanings that young people attribute to family. Juana (20 years old) highlights the blurred boundaries she glimpses in gender relations in family and friendship ties when she traveled to Paraguay when she was 13 years old.

I came from here [CABA], to go wherever I wanted, I don't know, to have male friends. It was impossible to have male friends there. A friendship between women and men, forget about it! There's already something going on. Not even with cousins, you could have so much friendship or affection because they already confused everything. That is typical of Paraguay, it is very typical. [Juana]

Heath (2002) points out that studies on transitions from the home and the domestic tended to focus on young adults leaving the parental home to start living with a partner and made invisible other intimate ties that are significant in youth biographies. Upon arriving in the CABA, Solanch and Edrul mention that older people, such as their neighbors, played an important role in their upbringing. For Lolo (18 years old) and Facu (19 years old), the formation of new family assemblies generates bonds with a stepsister and stepfather, who are valued and considered "family" and are associated with the presence of help and affection, more than with blood ties.

Maintaining bonds with other relatives such as grandparents, aunts, uncles, or cousins in different cities is also important for the interviewees. This occurs especially during vacation periods or at times of return.

It was like, “Oh, how nice!" To see my uncle again, because I didn't go to Córdoba 2 years ago, I haven't been able to go to Córdoba [Argentina] for a long time. [Lolo]

In other cases, family residence alternates between different cities. For Solanch (20 years old) and her parents, their arrival in the CABA does not imply their definitive settlement or the end of the bond with their family in Paraguay.

...my mother is Argentinian, but my father is a foreigner, he is Paraguayan. And I was born there, and when I was one year old, we moved here. And from here, I have lived here since I was one year old, that is it, I made my life here. In Caacupé [a city in Paraguay] I spent a year living there all the time. Then we were 
two, three months there, two, three months here, and it was like that... [Solanch]

Staying or moving does not necessarily occur sequentially or linearly. Migrations were commonly analyzed as movements from a place of origin to a final destination. The stability was considered a norm, fixing people and their practices to territories and ignoring that mobilities express multiple dynamics, simultaneous and interconnected scales, blurring legal and symbolic boundaries (Glick Schiller and Salazar 2013; Schrooten, Salazar and Dias 2016).

\section{The Identity Trial}

Young migrants report experiences of discrimination at different points in their biographies. They experience these situations as real challenges to which they must spread various tactics to be accepted or integrated into public or private spaces. Generally, these experiences arise from encounters in which other individuals or groups assign them stereotypes based on their socioeconomic conditions, places of residence, ethnic or national origins, especially when they come from countries in the region such as Paraguay, Bolivia, or Peru.

Stereotyping is a process of naturalization of differences between individuals or groups that marks a symbolic and physical boundary between "us" and "they-the others." Discrimination is based on an elusive logic that seeks to avoid one's inadequacies to denigrate others. These processes are based on social categories to which certain negativized traits are assigned as natural and which justify various forms of violence on those who possess them (Gavazzo 2013; Jones and Ariza 2018; Reygadas 2020).
The production of stereotypes, stigmas, and forms of discrimination against migrants from Latin American countries in urban centers in Argentina-especially in the MABA-has been accentuated since the consolidation of the neoliberal model during the 1990s: the historical invisibilization was replaced by a hyper-visibilization of differences. Since that decade, these groups of migrants have been held responsible-by official discourse and the media-for the growing social problems generated by that model: poverty, unemployment, and urban violence, deficiencies in access to health, education, and housing. This stigmatization process was transferred towards the children of migrants born in Argentina-for example, some of the young people interviewed-who, although legally Argentinian, are identified in everyday interactions as "Bolivians," "Paraguayans," or "Peruvians" (Grimson and Caggiano 2012; Vaccotti 2017).

As José Luis reflects on, young people feel these repeated experiences as injustices that cause them daily discomfort.

I was discriminated against, you know, because I don't want to hurt anyone or anything, you know, but it hurts to be discriminated against because you come here to look for a future...So it's like the people here sometimes see you as you are invading their territory, it's like that, you know, and, obviously, they are going to be like that because there is a lot of competition. [José Luis]

Here, we see the centrality of the symbolic dimension in youth sociability. In the social and institutional scenarios in which they mobilize and develop their individuation processes, young people are permanently attentive to signs of approval, stigmatization, or humiliation from others. Faced with situations of 
contempt-especially when other significant people such as family members, partners, friends, or representatives of public institutions-perpetuate them, the subjects experience the denial of recognition as individuals, full members of the community, diminished in their rights and autonomy (Honneth 1995).

As José Luis synthesizes, by considering themselves as equal to others, young people especially feel the wounds caused by these forms of denial of respect experienced in the MABA because of their migrant status (Martuccelli 2007; Dubet 2017). However, while denouncing the injustice of these forms of contempt and discrimination, both in Argentina and in returns to Paraguay, he develops a hard work on himself, seeking to hide those symbols of the stigma that can convey social information about his origin, to be respected by others.

I am quick to change, to change, and to change, you see? When I went there [Paraguay] for a year, in three months I spoke again with the accent I used to speak before. It was hard for me, but I had to speak like that because otherwise, they would call me curepi. As if I wanted to become, I don't know, you know, "Oh, you come here and speak Spanish" [laughs]. So I tried to speak... Then it was hard for me to speak because I had already learned Spanish well. There we use Spanish, in Asuncion, we speak Spanish and Guarani. [José Luis]

This feeling of shame concerning the use of the language generates marks in the subjectivities of young migrants like Nora (19 years old), especially when they attend school.

Because on top of that it was hard for me to speak Spanish, it's like I spoke a little bit in Guarani and a little bit in Spanish. At school, I tried not to speak too much. I was always very shy. I don't know, I was not very sociable. I was very introverted, I swallowed everything... [Nora]

In contrast to these scenarios of discrimination and exclusion, in some institutions and social organizations that promote the exercise of rights in poor neighborhoods, young migrants construct social experiences that are highly valued and understood as exceptions, shelters, in which they choose to participate because they feel recognized as "individuals."

In this type of institution and social organizations, spaces and times of meeting, coexistence, and work with others are generated in which young people feel listened to and treated as individuals.

Interviewer: What do you like most about your experience at COOPA?

Juan: The treatment of each of the teachers. Apart from doing graphic design, we do literacy and job orientation and each teacher tries to integrate you in each group, that's one of the things I liked: the support they give you. On top of that, if they see you are not well, they ask you, "How are you?" They keep track of you, that sort of thing...

In these institutional experiences, young people spread their agencies and generate new possibilities of living, working, and acting in a public space, a scenario of intersubjective recognition between young people and adults. This generates the power to reinvent a "we" that functions as a collective mediator in intersubjective bonds. From these institutional experiences, young people create and appropriate new senses of equality and freedom. In this way, citizenship ceases to be an abstract concept to become a concrete and everyday way of living together with other people (Dubet 2017). 


\section{Conclusions}

In their migratory experiences, young people from popular sectors of the MABA, Argentina, face three major social trials linked to each other: socio-labor; family; identity. As we developed in the article, about each of these challenges these people spread and connect a heterogeneity of biographical events and personal meanings. At the same time, as shown in Table 2, we identify for each trial a series of common and interconnected coercions, supports, and elasticities, in relation to which these young people individualize themselves and draft their agencies, act in other ways.

Table 2. Social trials, coercions, supports, and elasticities in the migratory experiences and agencies of young people of popular sectors of MABA

\begin{tabular}{|c|c|c|c|}
\hline SOCIAL TRIALS & COERCIONS & SUPPORTS & ELASTICITIES \\
\hline Socio-labor & $\begin{array}{l}\text { Stigma and socio-economic } \\
\text { conditions in accessible but } \\
\text { precarious neighborhoods } \\
\text { Intergenerational transmission } \\
\text { of precarious, informal, or } \\
\text { undervalued work options }\end{array}$ & $\begin{array}{c}\text { Offer of creative training } \\
\text { New ways of participation } \\
\text { Spaces of receptive sociability } \\
\text { Family networks }\end{array}$ & $\begin{array}{l}\text { Search for and concretion of new } \\
\text { employment and residential } \\
\text { opportunities }\end{array}$ \\
\hline Family & $\begin{array}{l}\text { Discontinuities and family break- } \\
\qquad \text { ups } \\
\text { Silenced young people voices }\end{array}$ & $\begin{array}{l}\text { New ways of support, } \\
\text { recognition, and meaningful } \\
\text { affective bonds in multiple spaces } \\
\text { of sociability }\end{array}$ & $\begin{array}{l}\text { Strategies to sustain family } \\
\text { bonds through mobile links }\end{array}$ \\
\hline Identity & $\begin{array}{l}\text { Discrimination linked to migrant, } \\
\text { ethnic, generational, and socio- } \\
\text { economic conditions } \\
\text { Symbolic and material boundaries } \\
\text { Hyper-visibility of community or } \\
\text { national differences and identities }\end{array}$ & $\begin{array}{l}\text { Institutions or social organizations } \\
\text { that function as material, affective, } \\
\text { and symbolic shelters }\end{array}$ & $\begin{array}{l}\text { Strategic use of social } \\
\text { information they transmit in } \\
\text { daily exchanges to diminish or } \\
\text { nullify stigma symbols } \\
\text { Articulation of internal, } \\
\text { personal, and external } \\
\text { intersubjective aspects of their } \\
\text { identities }\end{array}$ \\
\hline
\end{tabular}

Source: Self-elaboration.

In the migratory processes analyzed, the configuration of these youth agencies on the move reveals what we call border-links. These processes set out the tensions between the establishment of relationships with oth- ers and the edges that draw up these bonds and, at the same time, express the tensions between the distances/ closeness of these relationships, as well as the blurring of their limits and the senses associated with them. 
Border-links that close. From personal and family practices, young people develop strategies to become linked and integrate themselves to the conditions of the labor and residential markets, under the coercion and symbolic and material limits imposed on migrants: precarious housing, low-wage informal jobs, discrimination, and stigmatization. Faced with these limits established by markets or hegemonic discourses about migration, young people find interstices that break with crystallized logic. Thus, the presence of social bonds such as family, neighborhood, or institutional networks introduce new ways of living-for example, in the use of land through the transfer of land among family members-and transit through spaces that are valued shelters and that, in turn, enable the possibility of staying.

Border-links that open. In the presence of legal and symbolic borders, such as those established between countries, cities, or even areas within the same city, the constant migratory-residential movements which young people describe as significant events not only question these formal boundaries: in contexts that force members of these families to distance themselves physically or that produces new encounters with other people who become emotionally important, borders of what is supposed to be family, fraternal, and affective are broken, altered, and (re)created. In these processes young people observe es coping and facing these situations supported by their emotions that transit not only between pain, discomfort, or displeasure but also from recognition and appreciation. In this regard, the creation of new relationships of trust, in particular those enabled by the institutions in which these young people begin to participate, makes it possible to redefine and rethink the bonds of the family environment and friendship crossed by the (im)mobilities. At the same time, this encounter stresses the frontiers of identity by recreating the relationship with themselves, their desires, their expectations, and their rights, not reduced to their status as migrants or "children of migrants."

The articulation between the sociological perspective of the individuation and the methodological strategy of the biographical narratives has allowed us to identify the discontinuities and the common evidence present in the migratory experiences and the mobilities of these young people. In this process, we identify some supports, tactics, and strategies that mobilize these people individually and collectively, around themselves and others, to create shelters and face such challenges.

In this way, we make visible the chiaroscuros and elasticities present in the social, political, and economic structures that produce social inequalities and injustices. We consider that this elastic perspective of the social is valuable both for the social sciences and for interventions and public policies, since it allows us to glimpse different forms of agency, linking, symbolic, and institutional supports through which young people from popular sectors find new possibilities to constitute themselves as individuals and citizens, appropriating and exercising their rights.

\section{Acknowledgments}

This article is based on research projects financed by the University of Buenos Aires and the National Scientific and Technical Research Council, Argentina. 


\section{References}

Aguiló, Victoria and Juan Wahren. 2014. “The Popular High Schools of Argentina as 'Fields of Social Experimentation."' Argumentos (México, DF) 27(74):97-114.

Araujo, Kathya and Danilo Martuccelli. 2010. “Individuation and the Work of Individuals." Educação e pesquisa 36:77-91.

Araujo, Kathya and Danilo Martuccelli. 2012. Desafíos comunes. Retratos de la sociedad chilena y sus individuos [Common Challenges. Portraits of Chilean Society and Its Individuals]. Santiago de Chile: LOM.

Araujo, Kathya and Danilo Martuccelli. 2014. "Beyond Institutional Individualism. Agentic Individualism and Individuation Process in Chilean Society." Current Sociology 62(1):24-40.

Bertaux, Daniel and Isabelle Bertaux-Wiame. 1980. Une enquête sur la boulangerie artisanale en France [A Survey of Artisanal Bakery in France]. Paris: Cordes.

Chamberlayne, Prue, Joanna Bornat, and Tom Wengraf. 2000. "Introduction: The Biographical Turn." Pp. 1-30 in The Turn to Biographical Methods in Social Science: Comparative Issues and Examples, edited by P. Chamberlayne, J. Bornat, and T. Wengraf. London: Routledge.

Chaves, Mariana. 2010. Jóvenes, territorios y complicidades. Una antropología de la juventud urbana [Young People, Territories, and Complicities. An Anthropology of Urban Youth]. Buenos Aires: Espacio.

Chernobilsky, Lidia Beatriz. 2007. “El uso de computadora como auxiliar en el análisis de datos cualitativos [The Use of the Computer as an Aid in the Analysis of Qualitative Data]." Pp. 239-273 in Estrategias de investigación cualitativa [Qualitative Research Strategies], edited by I. Vasilachis de Gialdino. Buenos Aires: Gedisa.

Corbally, Melissa. 2011. Making Sense of the Unbelievable: A Biographical Narrative Study of Men's Stories of Female Abuse. Ph.D. Dissertation. University of Salford, Salford.

Cotton, Brandi and Donna Schwartz-Barcott. 2016. "Residential Instability among Low-Income Families: A Concept Analysis." Archives of Psychiatric Nursing 30(2):257-261.

Coulter, Rory, Maarten van Ham, and Allan Findlay. 2015. "Re-Thinking Residential Mobility: Linking Lives through Time and Space." Progress in Human Geography 40(3):352-374.
Cravino, María C. 2016. "Desigualdad urbana, inseguridad y vida cotidiana en asentamientos informales del Área Metropolitana de Buenos Aires [Urban Inequality, Insecurity, and Daily Life in Informal Settlements of the Metropolitan Area of Buenos Aires]." Etnografías Contemporáneas 2(3):56-83.

Crivello, Gina. 2015. “'There's No Future Here': The Time and Place of Children's Migration Aspirations in Peru." Geoforum 62:38-46.

Dako-Gyeke, Mavis. 2016. “Exploring the Migration Intentions of Ghanaian Youth: A Qualitative Study." Journal of International Migration and Integration 17(3):723-744.

De Freitas, Patricia. 2014. "Family Life and Labor of Young Migrants in the Industry of Confection." REMHU: Revista Interdisciplinar da Mobilidade Humana 22(42):231-246.

Denzin, Norman and Yvonna S. Lincoln, eds. 2011. The Sage Handbook of Qualitative Research. Thousand Oaks, CA: Sage.

Di Leo, Pablo Francisco and Ana Clara Camarotti. 2013. "Quiero escribir mi historia". Vidas de jóvenes en barrios populares ["I Want to Write My Story." Young People's Lives in Popular Neighborhoods]. Buenos Aires: Biblos.

Di Leo, Pablo Francisco and Ana Clara Camarotti. 2015. Individuación y reconocimiento. Experiencias de jóvenes en la sociedad actual [Individuation and Recognition. Young People Experiences in Current Societies]. Buenos Aires: Teseo.

Di Leo, Pablo Francisco and Ana Arias. 2019. Jóvenes e instituciones: El derecho a ser en barrios populares [Young People and Institutions. The "Right to Be" in Popular Neighborhoods]. Buenos Aires: Espacio.

Di Virgilio, Maria Mercedes, Mariana Marcos, and Gabriela Mera. 2015. “Las ciudades dentro de la ciudad: características sociodemográficas y habitacionales de la Ciudad de Buenos Aires según sus tipos de hábitat [The Cities within the City: Socio-Demographic and Housing Characteristics of the City of Buenos Aires According to Their Habitat Types]." Población de Buenos Aires 12(22):33-57.

Dubet, François. 2010. Sociología de la experiencia [Sociology of Experience]. Madrid: UCM, CIS.

Dubet, François. 2017. Lo que nos une. Cómo vivir juntos a partir de un reconocimiento positivo de la diferencia [What Unites Us. How 
to Live Together from a Positive Recognition of Difference]. Buenos Aires: Siglo XXI.

Fischer-Rosenthal, Wolfram. 2000. “Biographical Work and Biographical Structuring in Present-Day Societies.” Pp. 109-125 in The Turn to Biographical Methods in Social Science: Comparative Issues and Examples, edited by P. Chamberlayne, J. Bornat, T. Wengraf. London: Routledge.

Frändberg, Lotta. 2014. "Temporary Transnational Youth Migration and Its Mobility Links." Mobilities 9(1):146-164.

Gavazzo, Natalia. 2013. “No soy de aquí, ni soy de allá... Alterización y categorías de identificación en la generación de los hijos de inmigrantes bolivianos y paraguayos en Buenos Aires [I Am Not from Here, Nor Am I from There... Alterization and Identification Categories in the Generation of Children of Bolivian and Paraguayan Immigrants in Buenos Aires]." Claroscuro 12:73-95.

Gil Araujo, Sandra and Claudia Pedone. 2014. “Introducción. Familias migrantes y estados: vínculos entre Europa y América Latina [Introduction. Migrant Families and States: Links between Europe and Latin America]." Papelesdel CEIC 2:1-24.

Giralt, Rosa. 2016. “Transnational Processes of Identification and Belonging among Children and Young People of Migrant Descent." Identities and Subjectivities 4(103):2-17.

Glaser, Barney and Anselm L. Strauss. 1967. The Discovery of Grounded Theory: Strategies for Qualitative Research. New York: Aldine Publishing.

Glick Schiller, Nina and Noel Salazar. 2013. "Regimes of Mobility across the Globe." Journal of Ethnic and Migration Studies 39(2):183-200.

Gómez-Esteban, Jairo. 2016. “El acontecimiento como categoría metodológica de investigación social [The Event as a Methodological Category of Social Research]." Revista Latinoamericana de Ciencias Sociales, Niñez y Juventud 14(1):133-144.

Grimson, Alejandro and Sergio Caggiano. 2012. "Xenofobias descontroladas [Uncontrolled Xenophobias]." Pp. 61-78 in Racismo, violencia y política. Pensar el Indoamericano, dos años después [Racism, Violence, and Politics. Thinking the Indo-American, Two Years Later], edited by S. Caggiano, M. Casullo, and M. Cravino. Los Polvorines: UNGS.

Heath, Sue. 2002. "Domestic and Housing Transitions and the Negotiation of Intimacy." Pp. 117-136 in Young People in Risk Society: The Restructuring of Youth Identities and Transitions in Late
Modernity, edited by M. Cieslik and G. Pollock. Aldershot: Ashgate Publishing.

Honneth, Axel. 1995. The Struggle for Recognition: The Moral Grammar of Social Conflicts. Cambridge: Polity Press.

Huijsmans, Roy. 2018. “Becoming Mobile and Growing Up: A 'Generationed' Perspective on Borderland Mobilities, Youth, and the Household." Population, Space and Place 25(3):1-10.

Jones, Daniel and Lucía Ariza. 2018. “Discriminación social, vulneración de derechos y violencia institucional [Social Discrimination, Violation of Rights, and Institutional Violence]." Pp. 357-387 in La Argentina en el siglo XXI. Cómo somos, vivimos y convivimos en una sociedad desigual [Argentina in the XXI Century. How We Are, Live, and Coexist in an Unequal Society], edited by J. I. Piovani and A. Salvia. Buenos Aires: Siglo XXI.

Kaufmann, Vincent, Manfred Bergman, and Dominique Joye. 2004. "Motility: Mobility as Capital." International Journal of Urban and Regional Research 28(4):745-756.

King, Russel and Ronald Skeldon. 2010. "“Mind the Gap!' Integrating Approaches to Internal and International Migration." Journal of Ethnic and Migration Studies 36(10):1619-1646.

Kleidermacher, Gisele. 2017. "Social Representations of Senegalese Migrants in Buenos Aires (1995-2014)." Revistamexicana de sociología 79(1):65-92.

Kohler Riessman, Catherine. 2008. Narrative Methods for the Human Sciences. London: Sage.

Kok, Michael, Jan Coetzee, and Florian Elliker. 2017. “Overcoming the Divide: An Interpretive Exploration of Young Black South Africans' Lived Experiences of Upward Mobility in Central South Africa." Qualitative Sociology Review 13(1):56-73.

Leclerc-Olive, Michèle. 2009. "Temporalities of Experience: The Biographies and Events." Iberofórum. Revista de Ciencias Sociales de la Universidad Iberoamericana 4(8):1-39.

Lee, Helen. 2016. "'I Was Forced Here': Perceptions of Agency in Second Generation 'Return' Migration to Tonga." Journal of Ethnic and Migration Studies 42(15):2573-2588.

Lincoln, Yvonna S. and Norman Denzin, eds. 2003. Turning Points in Qualitative Research: Tying Knots in a Handkerchief. Walnut Creek, CA: Rowman Altamira. 
Marcús, Juliana. 2017. "'My House Is This Room': Female Migration and Precarious Housing in the City of Buenos Aires." Cuestiones de Sociología 17:1-19.

Martelotte, Lucía. 2015. “Cadenas globales de cuidado: entre la reproducción y la autonomía. Análisis de las migrantes peruanas en Argentina [Global Chains of Care: Between Reproduction and Autonomy. Analysis of Peruvian Migrants in Argentina]." Argumentos: revista de crítica social 17:178-210.

Martuccelli, Danilo. 2007. Cambio de rumbo. La sociedad a escala del individuo [Change of Course. Society at the Level of the Individual]. Santiago de Chile: LOM.

Martuccelli, Danilo. 2016. “La agencia y las funciones sociales de la realidad [Agency and the Social Functions of Reality]." Pp. 17-34 in Pensar la agencia en la crisis [Thinking the Agency in the Crisis], edited by B. Tejerina and G. Gatti. Madrid: CIS.

Martuccelli, Danilo and José Santiago. 2017. El desafío sociológico hoy: individuo y retos sociales [The Sociological Challenge Today: Individual and Social Challenges]. Madrid: CIS-Centro de Investigaciones Sociológicas.

Mikkelsen, Miguel and Pia Christensen. 2009. “Is Children's Independent Mobility Really Independent? A Study of Children's Mobility Combining Ethnography and GPS/Mobile Phone Technologies." Mobilities 4(1):37-58.

Moskal, Marta and Naomi Tyrrell. 2016. “Family Migration Decision-Making, Step-Migration and Separation: Children's Experiences in European Migrant Worker Families." Children's Geographies 14(4):453-467.

Pac-Salas, David and Tirso Ventura de Pedro. 2015. “Trajectories of Young People from Zaragoza (Spain) in Configurations of Working-Class Families." Revista Latinoamericana de Ciencias Sociales, Niñez y Juventud 13(2):981-994.

Pujadas-Muñóz, Juan José. 1992. El método biográfico: El uso de las historias de vida en ciencias sociales [The Biographical Method: The Use of Life Stories in Social Sciences]. Madrid: Centro de Investigaciones Sociológicas.

Punch, Samantha. 2007. "Negotiating Migrant Identities: Young People in Bolivia and Argentina." Children's Geographies 5(1-2):95-112.

Punch, Samantha. 2015. "Youth Transitions and Migration: Negotiated and Constrained Interdependencies within and across Generations." Journal of Youth Studies 18(2):262-276.
Raffaetà, Roberta, Loretta Baldassar, and Anita Harris. 2016. "Chinese Immigrant Youth Identities and Belonging in Prato, Italy: Exploring the Intersections between Migration and Youth Studies." Identities 23(4):422-437.

Reguillo, Rossana. 2012. Culturas juveniles. Formas politicas del desencanto [Youth Cultures. Political Forms of Disenchantment]. Buenos Aires: Siglo XXI.

Reygadas, Luis. 2020. "La construcción simbólica de las desigualdades [The Symbolic Construction of Inequalities]." Pp. 201-219 in Repensar las desigualdades. Cómo se producen y entrelazan las asimetrías globales (y qué hace la gente con eso) [Rethinking Inequalities. How Global Asymmetries Occur and Intertwine (and What People Do with It)], edited by E. Jelin, R. Motta, and S. Costa. Buenos Aires: Siglo XXI.

Roberti, Eugenia. 2017. "Towards a Critic of the Sociology of the Transition: Thoughts about the Paradox of Deinstitutionalization in the Analysis of Trajectories of Vulnerable Youth in Argentina." Estudios sociológicos 35(105):489-516.

Said, Shirly. 2018. "Young People in Popular High Schools: Between Individuation and Political Subjectivation." Universitas 28:141-157.

Salazar, Noel and Alan Smart. 2011. "Anthropological Takes on (Im)mobility." Identities 18(6):1-10.

Schrooten, Mieke, Noel Salazar, and Gustavo Dias. 2016. “Living in Mobility: Trajectories of Brazilians in Belgium and the UK." Journal of Ethnic and Migration Studies 42(7):1199-1215.

Sheller, Mimi and John Urry. 2006. "The New Mobilities Paradigm." Environment and Planning 38:207-226.

Skelton, Tracey. 2002. "Research on Youth Transitions: Some Critical Interventions." Pp. 100-116 in Young People in Risk Society: The Restructuring of Youth Identities and Transitions in Late Modernity, edited by M. Cieslik and G. Pollock. Aldershot: Ashgate Publishing.

Strauss, Anselm L. and Juliet Corbin. 1990. Basics of Qualitative Research: Grounded Theory Procedures and Techniques. Newbury Park, CA: Sage.

Tapia, Silvia Alejandra. 2016. “Bodies, Emotions, and Individuation: An Analysis of the Experiences of Youths That Perform Artistic and Sports Practices in Popular Neighborhoods of the City of Buenos Aires." Ph.D. Dissertation. University of Buenos Aires, Buenos Aires. 
Tapia, Silvia Alejandra. 2019. “Vulnerabilities, Mobilities and Corporalities of Young People Who Perform Practices in Arts and Sports in Popular Neighborhood of Buenos Aires." Physis: Revista de Saúde Coletiva 28(3):1-21.

Vaccotti, Luciana. 2017. "Migration Processes and Urban Informality Dynamics in Buenos Aires. Genealogy of a Sociological Problem." URBANA: Revista Eletrônica do Centro Interdisciplinar de Estudos sobre a Cidade 9(1):122-147. van Geel, Joan and Valentina Mazzucato. 2018. “Conceptualising Youth Mobility Trajectories: Thinking Beyond Conventional Categories." Journal of Ethnic and Migration Studies 44(13):2144-2162.

Vommaro, Pablo. 2015. Juventudes y politicas en la Argentina y en América Latina. Tendencias, conflictos y desafíos [Youth and Politics in Argentina and Latin America. Trends, Conflicts, and Challenges]. Buenos Aires: Grupo Editor Universitario, CLACSO.

\section{Citation}

Tapia, Silvia Alejandra and Pablo Francisco Di Leo. 2021. “Mobilities, Individuation, and Agencies: An Analysis Based on Young Migrants' Biographical Narratives in Buenos Aires, Argentina." Qualitative Sociology Review 17(3):108-128. Retrieved Month, Year (http://www.qualitativesociologyreview.org/ENG/archive_eng.php). DOI: https://doi.org/10.18778/1733-8077.17.3.06 